Preprint of the paper: Arquero, J.L., González González, J.M., Hassall, T., Joyce, J., Germanou, E., \& Asonitou, S. (2010). The approaches to learning of European accounting students. EuroMed Journal of Business, 5(3),

345-362. http://dx.doi.org/10.1108/14502191011080854

\title{
THE APPROACHES TO LEARNING OF EUROPEAN ACCOUNTING STUDENTS
}

\author{
José Luis Arquero Montaño \& José María González González \\ Universidad de Sevilla
}
Professor Trevor Hassall \& Professor John Joyce
Sheffield Hallam University

Eleni Germanou \& Sophia Asonitou

TEI Athens

Preprint version of the paper published in EuroMed Journal of Business, 5(3), 345-362.

http://dx.doi.org/10.1108/14502191011080854

Contact address:

José Luis Arquero Montaño

Departamento de Contabilidad y Finanzas

Universidad de Sevilla

Avenida Ramón y Cajal, 1

41018 - Sevilla (España)

e-mail: arquero@us.es

\begin{abstract}
Purpose: To identify the impact of differing teaching contexts on the approaches to learning of accounting undergraduates in different European countries by the use of a study process questionnaire.
\end{abstract}

Design/methodology/approach: The questionnaire used was Biggs' R-SPQ-2F (Biggs, 2001). This is a 20 item questionnaire that identifies the learning styles of individual students in terms of deep and surface approaches.

Findings: Significant differences were found in the approaches to learning of the students in the countries concerned. The differences were rooted in two subcomponents: motive and strategy. Gender differences were also identified.

Originality/value: A major factor in the development process of future accountants is the education process that they undertake. This study identifies a methodology that is capable of comparing accounting students in different countries and potentially identifying the underlying reasons why the quality of the learning outcomes achieved may differ under differing educational systems.

Keywords: Approaches to learning, comparative study, accounting and study process questionnaire.

Paper type: Research paper. 
Preprint of the paper: Arquero, J.L., González González, J.M., Hassall, T., Joyce, J., Germanou, E., \& Asonitou, S. (2010). The approaches to learning of European accounting students. EuroMed Journal of Business, 5(3),

345-362. http://dx.doi.org/10.1108/14502191011080854

\section{INTRODUCTION}

The future direction and prominence of accounting will be determined, to a major extent, by the competence of the accountants of the future. An important factor in the development of future accountants is the education process that they undertake. Consequently professional accounting bodies have become increasingly concerned with accounting education. A major concern is the continuing increase in the amount of accounting and financial regulations that students, and members, are required to learn. This has led to an acceptance that it is important to consider not only what accounting students are required to learn but how they learn, and the implications of this for continued professional development. The focus of this paper is on factors that influence approaches to learning: not the content of syllabi.

From a European perspective the concern about having the knowledge and ability to prepare a set of accounts before entering the profession has, to an extent, been overshadowed by wider initiatives in relation to the convergence of education within the European Community. The creation of the European Higher Education Area (EHEA) and the Bologna process has been identified as a key way to promote employability and mobility in Europe: giving European citizens the necessary competences to face the challenges of the new millennium (Bologna declaration, 1999). Convergence to the common objectives requires that each educational system will need specific, and differing, changes depending on the current state of the education system of that country. The implementation of the EHEA and the consequences for accounting education constitutes an interesting issue for future research. The EHEA is compulsory for the countries of the European Union who signed the Bologna Declaration. The mismatch between some educational systems and the objectives proposed by Bologna has led some universities to adopt educational solutions that are thought to be working effectively in other countries. Recent research (González et al., 2009) suggests that 
Preprint of the paper: Arquero, J.L., González González, J.M., Hassall, T., Joyce, J., Germanou, E., \& Asonitou, S. (2010). The approaches to learning of European accounting students. EuroMed Journal of Business, 5(3),

345-362. http://dx.doi.org/10.1108/14502191011080854

the mere translation of practices that have been successful in their countries of origin without taking into account contextual differences is problematical and could result in undesired consequences. They sound a note of warning that "there could be sound contextual and cultural differences, suggesting that: importing solutions without taking carefully into account the specific context in which those changes are going to be implemented might not be the answer; and a prior knowledge of environmental conditionings (personal, cultural and organizational) is essential" (González et al., 2009, p. 123).

The aim of this paper is to establish if the approaches to learning of accounting undergraduates in different European countries can be compared by the use of a study process questionnaire in order to identify if teaching contexts differ. Students from universities in three countries involved in the process of change initiated by the creation of the EHEA will be used as the basis for comparison. The consideration of these countries, Spain Greece and the UK, will allow us to identify differences among the approaches to learning between two countries that have to make major changes to their education systems in order to align with the objectives of the Bologna Declaration (Greece and Spain), as well as the differences between these two countries and the United Kingdom (where the education system was closer to the objectives).

This paper does not aim to generalize the results of this study to all the universities of Greece, Spain and United Kingdom, but it aims to identify some differences among the approaches to learning in the specific universities that could provide other European universities with important evidence and useful data. However, the results of this study should be interpreted and used with caution because of the differing contexts: policies, procedures and cultures. Using research methodologies developed in research into higher education the paper will propose a model of approaches to learning. The model suggests that the factors that will be instrumental in deciding the approach to learning adopted by students will be related to their 
Preprint of the paper: Arquero, J.L., González González, J.M., Hassall, T., Joyce, J., Germanou, E., \& Asonitou, S. (2010). The approaches to learning of European accounting students. EuroMed Journal of Business, 5(3),

345-362. http://dx.doi.org/10.1108/14502191011080854

personal characteristics and previous educational experience, and their perception of the learning context. The learning context includes the assessment system, the syllabus content and the pedagogy. The students' perceptions of these factors will lead them to make a decision as to the appropriate approach to learning to adopt.

\section{LITERATURE REVIEW}

There has been significant debate, particularly in the United States, about the future of accounting education. This has recognised that it is the quality of individuals rather than their technical skills which are vital for the future development of the profession. Sundem and Williams (1992) state that the increasing complexity of accounting arising out of the expansion in scope of the profession, changes in technology and growth of regulations has tended to produce the worst of all worlds: narrowly focused graduates with only a partial understanding of the accounting knowledge base. Zeff (1989) also expresses concern about the increased volume of technical knowledge that accountants are required to learn and notes that this has led to an increase in the overall size of accounting textbooks. He comments unfavourably on the potential effect of this on teaching methods: "textbooks and other teaching material could begin to resemble codifications of recommended practice, and accounting education programmes in tertiary institutions could become exercises in indoctrination" (Zeff, 1989, p. 166). The accounting knowledge base has grown tremendously over recent years and consequently it is becoming ever more difficult to squeeze it all into the present curriculum. The educational system needs to adopt a process oriented direction instead of a knowledge oriented system. Problems such as those specified above led to the Accounting Education Change Commission (AECC) stating in their Position Statement number one 'Objectives of Education for Accountants' (1990, p. 1) that "at the time 
Preprint of the paper: Arquero, J.L., González González, J.M., Hassall, T., Joyce, J., Germanou, E., \& Asonitou, S. (2010). The approaches to learning of European accounting students. EuroMed Journal of Business, 5(3),

345-362. http://dx.doi.org/10.1108/14502191011080854

of entry, graduates cannot be expected to have the range of knowledge and skills of experienced professional accountants. To attain and maintain the status of a professional accountant requires continual learning. Therefore pre-entry education should lay the base on which lifelong learning can be built. In other words graduates should be taught how to learn". Accounting graduates will learn how to become successful professional accountants if they adopt the life-long learning concept and thereby continually adapt to changes in the business environment.

How students study, rather than what they study, is an area that is increasingly attracting the attention of education researchers. Influential works in the area of students' approaches to learning are the empirical studies of Marton and Saljo (1976 and 1984). These studies identified two basic approaches to learning that may be adopted by students: "deep" and "surface" approaches. A student taking a deep approach tries to make sense of what is to be learnt in terms of ideas and concepts. A deep approach to learning has an internal emphasis in that reality becomes visible and intelligible; the student's conception of learning is 'understanding'. In contrast a student adopting a surface approach takes a more reproductive stance seeing what is to be learnt as a series of unconnected facts that need to be memorised for regurgitation at a later date. The perceived task is to merely reproduce the subject matter at a later date, for example in an exam. This is consistent with an external emphasis concerned with the demands of assessment, where knowledge is cut off from everyday reality. It therefore follows that the student's conception of learning is 'reproducing'.

It should however be noted that "deep" and "surface" approaches are not mutually exclusive options. Volet and Chalmers (1992) have suggested that student approaches to learning can be visualised as a continuum with deep and surface being the extremities. Gibbs (1995) notes that in general when a surface approach to learning is taken by students it nearly always leads to poorer quality learning outcomes. He also states that there is evidence to show that 
Preprint of the paper: Arquero, J.L., González González, J.M., Hassall, T., Joyce, J., Germanou, E., \& Asonitou, S. (2010). The approaches to learning of European accounting students. EuroMed Journal of Business, 5(3),

345-362. http://dx.doi.org/10.1108/14502191011080854

students can rote memorise not just content but also procedures. In accounting terms this would equate to not just rote learning facts, but whole processes such as discounted cash flow in investment appraisal.

Biggs (1993) version of the 3P model of classroom teaching provides a framework for an understanding of the attitudes of students to learning (Figure1). This describes a dynamic system with interactions between student factors, teaching context, learning focused activities and the learning outcomes. Biggs (1987, 1993a and 1993b) describes presage factors as those factors which exist before engagement that affect learning. Student factors in this context would be prior knowledge, ability and their preferred approaches to learning. Teaching factors could consist of content, teaching methods, assessment methods and the institutional procedures and culture. These factors combine to determine the "ongoing approaches to learning" and therefore ultimately the learning outcome. Importantly as indicated by the feedback loops within the diagram each factor affects every other factor. This means that the system is dynamic and continual adjustments based on the student's perceptions will be made. In this context Shuell (1986) emphasises the importance of the student's perceptions and actions rather than those of their teachers.

\section{[see FIGURE 1]}

The process level represents the contextual point at which the student chooses the appropriate approach to use. The student will decide, having been influenced by their personal factors and the teaching context, to adopt what they perceive to be the appropriate approach from along the deep/surface continuum for that situation. This means that it is the student's view of this dynamic context (which has been partly created by the teacher and by the teaching context) that will determine whether or not the desired outcomes are produced. Biggs (2001) states that responses in the process stage are a joint function of both individual characteristics and the teaching context, and that student and teacher are jointly responsible for the resultant 
Preprint of the paper: Arquero, J.L., González González, J.M., Hassall, T., Joyce, J., Germanou, E., \& Asonitou, S. (2010). The approaches to learning of European accounting students. EuroMed Journal of Business, 5(3),

345-362. http://dx.doi.org/10.1108/14502191011080854

outcome. The teacher is responsible for structuring the teaching contexts; the student engages with them. Biggs states: "Thus, an approach to learning describes the nature of the relationship between student, context and task" (Biggs, 2001, p. 137).

This study is consistent with the qualitative approach developed primarily by Marton and Saljo, and developed by Biggs, Entwistle and Ramsden. The approach identifies the factors that influence the quality of a student's learning outcomes. These factors will influence the choice of approach adopted by the student in order to reach the outcomes as perceived by the student. The emphasis here is on the student's perception: this is important because it is the student who is involved in the act of learning. Given that it is the student that realises the perceptions of the relevant phenomena the research methodology is primarily qualitative. Biggs (2001) has produced a two factor study process questionnaire (SPQ). The instrument assesses the deep and surface approaches of students. The SPQ scores can be used for indicating quality at presage, process and product levels. In this paper we will be using the SPQ at the product level in order to identify if teaching contexts differ. In an ideal system it would be expected that students would operate at the highest level when engaging with learning activities. This would be consistent with a deep approach.

Recent research has indicated the importance of assessment in determining how students are oriented in their learning. Consequently, if we wish to generate high level outcomes it is of fundamental importance that the students perceive the assessment system as being consistent with a deep approach.

Curriculum design and study method also have an impact on students' perceptions of learning situations. Gibbs (1992) summarises the characteristics of the contextual factors that are associated with a surface approach as a heavy workload, an excessive amount of course material, a lack of opportunity to pursue subjects in depth, no freedom to choose the subjects to be studied and a lack of choice over the method of study. Many people involved in 
Preprint of the paper: Arquero, J.L., González González, J.M., Hassall, T., Joyce, J., Germanou, E., \& Asonitou, S. (2010). The approaches to learning of European accounting students. EuroMed Journal of Business, 5(3),

345-362. http://dx.doi.org/10.1108/14502191011080854

accounting education and training may feel that the above factors describe, in general terms, the situation facing accounting students.

\subsection{Approaches to learning, gender and academic performance}

Richardson (1993) stated that while the idea that male and female students in higher education differ in their approaches to learning is intrinsically a very plausible one, the few studies comparing students' approaches to learning (SAL) by gender typically found only slight and inconsistent differences. Furthermore, his results did not provide evidence of significant differences associated with gender in terms of their scores on individual items or subscales. In the same way, results by Byrne et al. (2002) found no gender differences in a sample of European students.

Severiens and Ten Dam (1994) conducted a meta-analysis of the existing literature. They conclude in their review that the deep and surface dimensions are gender sensitive. In a further work Severiens and Ten Dam (1998) indicated that gender differences occurred in most of the scales.

Hayes and Richardson (1995) approached the problem in a different way, concluding that, when the gendered nature of their discipline accords with the gendered quality of their learning environment, the approaches to studying of female students are more desirable than those of male students. Smith and Miller (2005) found that female students reported themselves to be consistent and regular in their study habits, regular in monitoring their understanding, and organised in note taking and assignment preparation, and that they obtained higher scores on the achieving strategy scale.

A plausible explanation of those inconsistencies could be provided by De Lange and Mavondo (2004), who indicate that the results of their investigation suggest that males do not fit into the theorised model of SAL: "specifically, male students can live with inconsistencies 
Preprint of the paper: Arquero, J.L., González González, J.M., Hassall, T., Joyce, J., Germanou, E., \& Asonitou, S. (2010). The approaches to learning of European accounting students. EuroMed Journal of Business, 5(3),

345-362. http://dx.doi.org/10.1108/14502191011080854

or contradictions associated with differences in sources of study motivation". Therefore, for these authors, responses from female students are consistent with theory but for males, high academic achievement can be associated with a surface approach.

\section{RESEARCH QUESTIONS}

The main research questions are as follows:

1. Are there differences between the learning approaches of Greek, Spanish and UK students?

2. Are there differences in learning approaches of Greek, Spanish and UK students associated with gender?

As there could be contextual differences that could influence this relationship the last question will be tested independently for each sub sample.

\section{METHODOLOGY}

\subsection{Participants and procedure}

The data for this study was collected via a questionnaire administered to groups of undergraduate accounting students in three different European countries (Spain, Greece and the UK). The data collection was anonymous and the instrument was administered during a teaching session to all of the students attending that session. A total of 1,103 undergraduate students from business, administration and finance related degrees in the three countries completed the questionnaire. A check was made to ensure there were no students of differing nationalities within the individual samples. The universities chosen are major institutions that are representative of the average universities of each country and therefore the results are indicative of differences in the population. Within the respective countries concerned the degrees must fulfil the same requirements to be implemented and are subject to the same 
Preprint of the paper: Arquero, J.L., González González, J.M., Hassall, T., Joyce, J., Germanou, E., \& Asonitou, S. (2010). The approaches to learning of European accounting students. EuroMed Journal of Business, 5(3),

345-362. http://dx.doi.org/10.1108/14502191011080854

systems of accreditation and quality assessment. The generalization of these results and conclusion could be affected and therefore should be interpreted in the light of this limitation. The primary focus of the research is exploratory in the sense of establishing a research approach that could be used to explore the differences identified and their underlying causes as a future research project.

Differences were tested in a two step design. In a first instance a multivariate model of analysis of variance (MANOVA) indicated, for each dependent variable (approach to learning score), the existence of differences associated with the two main factors (country and gender). In a second step, differences between countries were tested by using univariate analysis of variance (ANOVA) with weighted sub samples (in order to proxy for equally distributed samples by gender). Multiple and univariate ANOVA were considered adequate due to the robustness of $\mathrm{F}$ statistic.

Post hoc tests allowing obtaining multiple comparisons between means of a factor (country in this case) were performed. For the data, Dunnett's T3 post hoc test (pairwise comparison test based on the 'studentized' maximum modulus) was considered adequate given that this test is appropriate without need for assuming equal variances.

Differences by gender, which could be contextually different, were tested country by country. T-tests were performed along with the Levene test for homogeneity of variance with the corrected t-test significance shown when applicable.

The SPSS 13.0 statistical package was used to process the data and perform the tests.

\subsection{Research instrument}

The questionnaire used was the revised version of the study process questionnaire (R-SPQ2F, Biggs et al., 2001). The original SPQ is a 42 items self-report instrument developed by Biggs (1987) to evaluate student approaches to learning (SAL) in the higher education 
Preprint of the paper: Arquero, J.L., González González, J.M., Hassall, T., Joyce, J., Germanou, E., \& Asonitou, S. (2010). The approaches to learning of European accounting students. EuroMed Journal of Business, 5(3),

345-362. http://dx.doi.org/10.1108/14502191011080854

context. The study process questionnaire conceptualises student approaches to learning in terms of the two approaches to learning (deep and surface). Each approach is then conceptualized in terms of the combination of students' motive to learn and the corresponding strategy they use (see table 1).

\section{Table 1: Components of the SPQ}

\begin{tabular}{l|ll}
\hline & Surface & Deep \\
\hline Motive & Fear of failure & Intrinsic interest \\
Strategy & Narrow target, rote learn & Maximise learning \\
\hline
\end{tabular}

\section{Source: Biggs et al. (2001).}

The surface motive is mainly instrumental: the student aims to meet requirements minimally, balancing working too hard and failing. The surface strategy is reproductive: the learning objectives are limited to the minimum, the bare essentials, which are rote learnt. In the deep approach the motive is mainly intrinsic. Students work at the subject to acquire competence and a deep understanding of the concepts. The corresponding strategy is meaningful (read widely, inter-relate with relevant concepts and knowledge).

As Zeegers (2002) states, the SPQ was developed in a higher education environment that has changed dramatically with respect to crucial factors. That change as well as other concerns raised by researchers (Kember et al., 1999; Richardson, 2000) led to revisions of the instrument (Biggs et al., 2001; Fox et al., 2001; Zeegers, 2002). The revised SPQ by Biggs et al. (2001) was developed in order to obtain a short questionnaire that could allow teachers to evaluate the learning approach of their students using fewer items than other questionnaires. The revised SPQ focused on two main approaches: deep and surface. In the first stage the original pool of items from the deep and surface scales of the original were examined, changing and rewording those that were considered unsuitable. From this pool of items, 20 items where selected to maximise the reliability and contribution to the scale (high regression coefficients and low error terms). The Cronbach's alpha values for the resulting scales in the 
Preprint of the paper: Arquero, J.L., González González, J.M., Hassall, T., Joyce, J., Germanou, E., \& Asonitou, S. (2010). The approaches to learning of European accounting students. EuroMed Journal of Business, 5(3),

345-362. http://dx.doi.org/10.1108/14502191011080854

original study were 0.73 for deep approach and 0.64 for surface approach: these are considered to be acceptable.

\section{RESULTS}

Responses were gathered from 1,103 undergraduate students from business, administration and finance related degrees in the three countries (Table 2). The overall sample had an average age of 20 years.

Table 2. Distribution of sample by gender and country

\begin{tabular}{lllrrrr}
\hline & & Spain & Greece & \multicolumn{1}{c}{ UK } & \multicolumn{1}{c}{ Total } \\
\hline Gender & \multirow{2}{*}{1 male } & Count & 114 & 162 & 230 & 506 \\
& & $\%$ within sub-sample & $33.0 \%$ & $44.0 \%$ & $62.0 \%$ & $46.7 \%$ \\
& \multirow{2}{*}{2 female } & Count & 231 & 206 & 141 & 578 \\
& & $\%$ within sub-sample & $67.0 \%$ & $56.0 \%$ & $38.0 \%$ & $53.3 \%$ \\
& Count & 345 & 368 & 371 & 1084 \\
& not.indicated. & 18 & 0 & 1 & 19 \\
\hline & Total & 363 & 368 & 372 & 1,103 \\
\hline
\end{tabular}

The Spanish sub-sample contains 363 students (231 female and 114 male). The Greek sub sample is 368 students (206 female and 162 male) and the UK sub sample is 371 students (141 female and 230 male). As can be seen from Table 2, the percentage of female students enrolled on accounting courses in Spain and Greece is much higher than in the UK. There were 19 students that did not indicate their gender.

The reliability (Cronbach's Alpha) of the instrument for the sample is considered adequate (Table 3).

Table 3. Instrument reliability (Cronbach's Alpha)

\begin{tabular}{lrrr}
\hline & Spain & Greece & \multicolumn{1}{c}{ UK } \\
\hline Deep approach & .759 & .702 & .705 \\
Surface approach & .784 & .699 & .707 \\
\hline
\end{tabular}

The reliability analysis indicates adequate internal consistency for the main scales (deep and surface approaches). For the Spanish sub-sample the Cronbach's alpha is .759 for deep approach scale and .784 for surface approach scale. The alpha coefficients obtained for the 
Preprint of the paper: Arquero, J.L., González González, J.M., Hassall, T., Joyce, J., Germanou, E., \& Asonitou, S. (2010). The approaches to learning of European accounting students. EuroMed Journal of Business, 5(3),

345-362. http://dx.doi.org/10.1108/14502191011080854

Greek sub-sample are similar: .702 deep score and .699 surface score and for the UK: .705 deep score and .707 surface score. These values are similar to the coefficients reported in the original study by Biggs et al. (2001). In fact they are slightly higher for the surface scale which is systematically considered the weakest scale in terms of internal consistency (Richardson, 2000; Zeegers, 2002).

The main aim of this study is to test if there are differences between the learning approaches of Greek, Spanish and UK students. A second question for the study is to examine if there are differences in learning approaches associated with gender. In order to test differences on the scores by factors (gender and country) multiple analysis of variance (MANOVA) tests were performed (Table 4). MANOVA is a generalized procedure to test the differences between means in multivariate designs.

Table 4. Multiple analysis of variance for the deep approach

\begin{tabular}{llrrrrr}
\hline & Source of variation & \multicolumn{1}{c}{$S S$} & $D F$ & $M S$ & $F$ & Sig of $F$ \\
\hline Deep score & Within+residual & 31094.19 & 1048 & 29.67 & & \\
& Country & 458 & 2 & 229 & 7.72 & 0,000 \\
& Gender & 89.70 & 1 & 89.70 & 3.02 & 0,082 \\
& (Model) & 626.08 & 3 & 208,69 & 7.03 & 0,000 \\
& (Total) & 31720.27 & 1051 & 30.18 & & \\
Deep motive & Within+residual & 11067.81 & 1060 & 10.44 & & \\
& Country & 176.58 & 2 & 88.29 & 8.46 & 0,000 \\
& Gender & 49.60 & 1 & 49.60 & 4.75 & 0,030 \\
& (Model) & 275.35 & 3 & 91.78 & 8.79 & 0,000 \\
& (Total) & 11343.16 & 1063 & 10.67 & & \\
& Within+residual & 9673.41 & 1056 & 9.16 & & \\
& Country & 88.6 & 2 & 44.3 & 4.84 & 0,008 \\
& Gender & 4.62 & 1 & 4.62 & 0.50 & n.s. \\
& (Model) & 96.55 & 3 & 32.18 & 3.51 & 0,015 \\
& (Total) & 9769.97 & 1059 & 9.23 & & \\
\hline
\end{tabular}

SS: sum of squares, DF: degrees of freedom, MS: SS/DF

It can be seen that for the deep approach scores (see Table 4) there are significant differences between the countries (sig. of $\mathrm{F}<1 \%$ ). This difference is also reflected in both the motive and strategy scores. There are also significant differences by gender, which are principally derived from differences in the motive component of the total score. 
Preprint of the paper: Arquero, J.L., González González, J.M., Hassall, T., Joyce, J., Germanou, E., \& Asonitou, S. (2010). The approaches to learning of European accounting students. EuroMed Journal of Business, 5(3),

345-362. http://dx.doi.org/10.1108/14502191011080854

Table 5. Multiple analysis of variance for the surface approach

\begin{tabular}{llrrrrr}
\hline & Source of variation & \multicolumn{1}{c}{ SS } & DF & \multicolumn{1}{c}{ MS } & F & Sig of $F$ \\
\hline Surface score & Within+residual & 37627.46 & 1039 & 36.22 & & \\
& Country & 4239.58 & 2 & 2119.79 & 58.53 & 0.000 \\
& Gender & 730.88 & 1 & 730.88 & 20.18 & 0.000 \\
& (Model) & 5346.16 & 3 & 1782.05 & 49.21 & 0.000 \\
& (Total) & 42973.62 & 1042 & 41.24 & & \\
Surface motive & Within+residual & 12190.81 & 1057 & 11.53 & & \\
& Country & 820.74 & 2 & 410.37 & 35.58 & 0.000 \\
& Gender & 283.35 & 1 & 283.35 & 24.57 & 0.000 \\
& (Model) & $124 ., 8$ & 3 & 415.93 & 36.06 & 0.000 \\
& (Total) & 13438.61 & 1060 & 12.68 & & \\
& Within+residual & 12367.64 & 1060 & 11.67 & & \\
& Country & 1427.59 & 2 & 713.79 & 61.18 & 0.000 \\
& Gender & 97.97 & 1 & 97.97 & 8.4 & 0.004 \\
& (Model) & 1588.9 & 3 & 529.63 & 45.39 & 0.000 \\
& (Total) & 13956.54 & 1063 & 13.13 & & \\
\hline
\end{tabular}

SS: sum of squares, DF: degrees of freedom, MS: SS/DF

As indicated in Table 5 the differences in surface approach scores are to be statistically significant at a higher level for both factors and in all the scores, all these differences are significant at $1 \%$ level.

The MANOVA analysis in Tables 4 and 5 indicates differences due to gender and different distributions by gender between countries (Chi square sig: .000). In order to compare means by country isolating the gender variable, a univariate ANOVA analysis with weighted samples to proxy for a homogenous sample in terms of gender were used. Therefore the mean of the weighted sample indicates the mean of a sample equally distributed by gender. The differences associated with gender could be contextually driven and consequently the effect of gender will be analysed country by country later in the paper.

Table 6 presents the descriptive statistics and the significance of the ANOVA analysis for the deep approach scores by country (using the weighted cases). The results indicate that there are significant differences between countries in all of the scores. 
Preprint of the paper: Arquero, J.L., González González, J.M., Hassall, T., Joyce, J., Germanou, E., \& Asonitou, S. (2010). The approaches to learning of European accounting students. EuroMed Journal of Business, 5(3), 345-362. http://dx.doi.org/10.1108/14502191011080854

Table 6. Deep scores by country (weighted sample)

\begin{tabular}{|c|c|c|c|c|c|c|}
\hline & & Mean & Std Dev. & Min. & $\operatorname{Max}$ & Anova sig \\
\hline \multirow[t]{3}{*}{ Deep } & Spain & 29.35 & 5.69 & 13 & 45 & 0.000 \\
\hline & Greece & 29.93 & 5.32 & 15 & 46 & \\
\hline & UK & 28.39 & 5.35 & 12 & 49 & \\
\hline \multirow[t]{3}{*}{ D. Motive } & Spain & 15.48 & 3.28 & 6 & 23 & .000 \\
\hline & Greece & 15.55 & 3.27 & 5 & 25 & \\
\hline & UK & 14.63 & 3.18 & 6 & 25 & \\
\hline \multirow[t]{3}{*}{ D. Strategy } & Spain & 13.90 & 3.09 & 5 & 24 & 0.005 \\
\hline & Greece & 14.38 & 2.96 & 6 & 24 & \\
\hline & UK & 13.77 & 3.00 & 6 & 24 & \\
\hline
\end{tabular}

ANOVA indicates that differences between countries exist but in order to know which countries differ from others post hoc comparisons are needed. Table 7 presents the results of the post hoc T3 Dunnett test.

Table 7. Comparison of deep scores by country (Dunnet)

\begin{tabular}{lllrr}
\hline & Sample $(I)$ & Sample $(J)$ & Mean differ. $(I-J)$ & \multicolumn{1}{c}{ Sig. } \\
\hline Deep score & Spain & Greece & -0.58 & n.s. \\
& Spain & UK & 0.96 & 0.029 \\
& Greece & UK & 1.55 & 0.000 \\
& & & & \\
Deep Motive & Spain & Greece & -0.07 & n.s. \\
& Spain & UK & 0.85 & 0.000 \\
& Greece & UK & 0.92 & 0.000 \\
& & & & \\
Deep Strategy & Spain & Greece & -0.48 & 0.051 \\
& Spain & UK & 0.13 & n.s. \\
& Greece & UK & 0.61 & 0.006 \\
\hline
\end{tabular}

The results in Table 7 indicate that for the deep approach, Greek and Spanish students obtain significantly higher scores than the UK students. This is mainly due to the motive component. This suggests that Greek and Spanish students are more intrinsically motivated towards the subject of accounting and are more willing to work at the subject to acquire competence and a deep understanding of the concepts. Greek students again obtain the highest scores for the strategy component but here the Spanish students present scores that are closer to those of the 
Preprint of the paper: Arquero, J.L., González González, J.M., Hassall, T., Joyce, J., Germanou, E., \& Asonitou, S. (2010). The approaches to learning of European accounting students. EuroMed Journal of Business, 5(3),

345-362. http://dx.doi.org/10.1108/14502191011080854

UK students. The Greek students again are strongly intrinsically motivated prepared to read widely and inter-relate with relevant concepts and knowledge.

Tables 8 and 9 show the surface approaches scores analysed using the same approach.

Table 8. Surface cores by country (weighted sample)

\begin{tabular}{|c|c|c|c|c|c|c|}
\hline & & Mean & Std Dev. & Min. & $\operatorname{Max}$ & Anova sig \\
\hline \multirow[t]{3}{*}{ Surface } & Spain & 24.39 & 6.37 & 11 & 42 & 0.000 \\
\hline & Greece & 29.07 & 6.04 & 10 & 44 & \\
\hline & UK & 26.72 & 5.79 & 11 & 48 & \\
\hline \multirow[t]{3}{*}{ S. Motive } & Spain & 10.97 & 3.37 & 5 & 21 & 0.000 \\
\hline & Greece & 13.04 & 3.70 & 5 & 25 & \\
\hline & UK & 12.21 & 3.24 & 5 & 24 & \\
\hline \multirow[t]{3}{*}{ S. Strategy } & Spain & 13.36 & 3.68 & 5 & 23 & 0.000 \\
\hline & Greece & 16.04 & 3.27 & 5 & 25 & \\
\hline & UK & 14.51 & 3.35 & 6 & 25 & \\
\hline
\end{tabular}

Table 9. Comparison of surface scores by country (Dunnet)

\begin{tabular}{lllrl}
\hline & Sample $(I)$ & Sample $(J)$ & Mean differ. $(I-J)$ & Sig. \\
\hline Surface score & Spain & Greece & -4.68 & 0.000 \\
& Spain & UK & -2.33 & 0.000 \\
& Greece & UK & 2.35 & 0.000 \\
& & & & \\
Surface Motive & Spain & Greece & -2.07 & 0.000 \\
& Spain & UK & -1.24 & 0.000 \\
& Greece & UK & 0.83 & 0.001 \\
& & & & \\
Surface Strategy & Spain & Greece & -2.67 & 0.000 \\
& Spain & UK & -1.15 & 0.000 \\
& Greece & UK & 1.53 & 0.000 \\
\hline
\end{tabular}

These results indicate significant differences between countries at the $1 \%$ level for surface scores. Consistent with the previous tables, the highest scores are for the Greek students. It should be noted at this stage that Greek students recorded high scores in both deep and surface approaches to learning. Overall the Greek students present the highest scores and Spanish students the lowest surface scores. In the case of surface learning, the tables show significant differences between the scores for all three countries both in total and in the scores for surface motive and strategy. Surface learning is consistent with an extrinsic approach and is primarily concerned with the demands of assessment. The student is motivated by fear of 
Preprint of the paper: Arquero, J.L., González González, J.M., Hassall, T., Joyce, J., Germanou, E., \& Asonitou, S. (2010). The approaches to learning of European accounting students. EuroMed Journal of Business, 5(3),

345-362. http://dx.doi.org/10.1108/14502191011080854

failure to meet the perceived demands of assessment. Strategically the student focuses on rote learning only material that they believe will enable them to pass the assessment.

As previously discussed above there could be contextual factors that could influence and motivate different patterns of gender differences within each sub sample. Therefore gender differences are examined country by country. The results in terms of gender for the Spanish sample are shown in Table 10.

Table 10. Scores by gender (Spanish sample)

\begin{tabular}{llrrrr}
\hline & & & Mean & Std. dev & t-test sig \\
\hline Deep & male & 108 & 29.57 & 5.660 & n.s. \\
Score & female & 218 & 29.12 & 5.729 & \\
Deep & male & 110 & 15.58 & 3.363 & n.s. \\
Motive & female & 222 & 15.37 & 3.206 & \\
Deep & male & 110 & 14.05 & 3.015 & n.s. \\
Strategy & female & 219 & 13.75 & 3.174 & \\
Surface & male & 111 & 25.78 & 6.190 & 0.000 \\
Score & female & 218 & 22.95 & 6.270 & \\
Surface & male & 112 & 11.69 & 3.337 & 0.000 \\
Motive & female & 228 & 10.25 & 3.264 & \\
Surface & male & 112 & 14.04 & 3.667 & 0.001 \\
Strategy & female & 220 & 12.66 & 3.569 & \\
\hline
\end{tabular}

The table indicates that there are no differences in the deep approach scores for male and female Spanish students. However, male students in Spain score significantly higher than female students in their surface approach in total and on both sub scales.

Table 11. Scores by gender (Greek sample)

\begin{tabular}{lllrrr}
\hline & & $n$ & Mean & Std. dev & t-test sig \\
\hline Deep & male & 162 & 29.29 & 5.65 & 0.021 \\
Score & female & 206 & 30.57 & 4.92 & \\
Deep & male & 162 & 15.10 & 3.34 & 0.009 \\
Motive & female & 206 & 16.00 & 3.15 & \\
Deep & male & 162 & 14.19 & 3.16 & n.s. \\
Strategy & female & 206 & 14.58 & 2.74 & \\
Surface & male & 162 & 29.27 & 6.20 & n.s. \\
Score & female & 205 & 28.88 & 5.90 & \\
Surface & male & 162 & 13.34 & 3.90 & n.s. \\
Motive & female & 205 & 12.74 & 3.47 & \\
Surface & male & 162 & 15.93 & 3.29 & n.s. \\
Strategy & female & 206 & 16.15 & 3.26 & \\
\hline
\end{tabular}


Preprint of the paper: Arquero, J.L., González González, J.M., Hassall, T., Joyce, J., Germanou, E., \& Asonitou, S. (2010). The approaches to learning of European accounting students. EuroMed Journal of Business, 5(3),

345-362. http://dx.doi.org/10.1108/14502191011080854

Table 11 shows that female Greek students score significantly higher in terms of deep approach overall due to their higher scores in the motive component. Although male Greek students score slightly higher in terms of surface scores, as did their Spanish (again principally due to the motive component), these differences from the Greek female students are not statistically significant.

Table 12. Scores by gender (UK sample)

\begin{tabular}{llrrrr}
\hline & & \multicolumn{1}{c}{ Mean } & Std. dev & t-test sig \\
\hline Deep & male & 222 & 28.00 & 5.52 & n.s. \\
Score & female & 136 & 28.77 & 5.16 & \\
Deep & male & 226 & 14.36 & 3.24 & n.s. \\
Motive & female & 138 & 14.90 & 3.10 & \\
Deep & male & 225 & 13.65 & 3.12 & n.s. \\
Strategy & female & 138 & 13.88 & 2.88 & \\
Surface & male & 216 & 27.82 & 5.84 & 0.001 \\
Score & female & 131 & 25.61 & 5.54 & \\
Surface & male & 223 & 12.82 & 3.23 & 0.000 \\
Motive & female & 131 & 11.57 & 3.13 & \\
Surface & male & 223 & 14.95 & 3.40 & 0.017 \\
Strategy & female & 141 & 14.09 & 3.26 & \\
\hline
\end{tabular}

UK students exhibit a similar pattern to their Spanish counterparts. UK male students score higher in the surface approach in total and on both sub scales than their female counterparts. A major difference is in terms of the motive component (12.82 versus 11.57). Deep scores tend to be higher for female students but differences are not significant.

\section{DISCUSSION AND CONCLUSION}

Attention was drawn earlier in this paper to the statement from the Accounting Education Change Commission Statement number one 'Objectives of Education for Accountants' (1990, p. 1) that "pre-entry education should lay the base on which lifelong learning can be built. In other words graduates should be taught how to learn". The work of Marton and Saljo (1976 and 1984) has identified the importance of the approach to learning taken by the individual student in terms of a deep or surface approach. Biggs (1987, 1993a and 1993b) develops this 
Preprint of the paper: Arquero, J.L., González González, J.M., Hassall, T., Joyce, J., Germanou, E., \& Asonitou, S. (2010). The approaches to learning of European accounting students. EuroMed Journal of Business, 5(3),

345-362. http://dx.doi.org/10.1108/14502191011080854

into the 3P model of teaching and learning which explains the importance of presage factors as those factors that exist before engagement that affects learning. Student factors in this context would be prior knowledge, ability and their preferred approaches to learning. Teaching factors could consist of content, teaching methods, assessment methods and the institutional procedures and culture. These factors combine to determine the "ongoing approaches to learning" and therefore ultimately the learning outcome.

The purpose of the study was to identify if there are differences between Greek, Spanish and UK students in terms of learning approaches. This would then form a methodology capable of comparing accounting students in different countries and the potential to explore the underlying reasons why the quality of the learning outcomes achieved may differ under differing educational systems.

The results show that there are differences between the three sets of students. There is a statistically significant difference between the three countries concerned in respect of the deep approach. This is principally because of the scores recorded in the sub scale of deep motive. There is less evidence of a difference in terms of the scores for deep strategy. A further ANOVA analysis revealed the differences in the overall deep score and in the deep motive score to be between the UK and the other two countries, there being no significant difference between Spain and Greece. The deep approach is characterised by an internal emphasis in that reality becomes visible and intelligible; the student's conception of learning is 'understanding'. In the deep approach the influence of motive is mainly intrinsic; students work at the subject to acquire competence and a deep understanding of the concepts. This would infer that Spanish and Greek students are motivated to learn by intrinsic factors in terms of the subject itself and this creates a motivation to engage with the subject in terms of building a competence and deeper understanding of accounting. 
Preprint of the paper: Arquero, J.L., González González, J.M., Hassall, T., Joyce, J., Germanou, E., \& Asonitou, S. (2010). The approaches to learning of European accounting students. EuroMed Journal of Business, 5(3), 345-362. http://dx.doi.org/10.1108/14502191011080854

There are also significant differences between the two countries in terms of the scores recorded for the surface approach both in terms of the overall score and both sub scales of motive and strategy. These differences are confirmed by the ANOVA analysis. The surface approach implies an external emphasis with a focus on the demands of assessment and where knowledge is not seen as being part of everyday reality. It therefore follows that the student's conception of learning is 'reproducing'. The perceived task is to merely reproduce the subject matter at a later date, for example in an exam. This implies that a more instrumental approach is being taken by Greek students. In the surface approach the influence of motive is seen as a fear of failure. The learning objectives are reduced to a minimum and are rote learnt.

As previously noted the Greek students scored higher scores for both deep and surface approaches. The standard deviations are not higher than those for the other samples therefore the difference is not due to a greater variation within the sample. Maybe the Greek students have a more flexible or changeable approach. The results for the Spanish students present a higher difference between deep and surface scores than their European counterparts. Students exhibiting a high positive difference between deep and surface scores tend towards a consistently deep approach whereas students showing high negative difference tend towards a consistently surface approach.

Gender differences were revealed between the students of all three countries. In the Greek sample female students score higher in the deep approach and this is primarily due to the motivation factor. This suggests that the Greek females have a high intrinsic motivation towards the subject of accounting. Male students in Spain and the UK score higher in the surface approach in total and on both sub scales than their female counterparts. This implies a greater fear of failure and a tendency towards narrow targets and a greater dependency on rote learning. This confirms the inconsistencies found in previous studies. Severiens and Tan Dam (1998) stressed the need for a greater number of studies in order to draw conclusions. 
Preprint of the paper: Arquero, J.L., González González, J.M., Hassall, T., Joyce, J., Germanou, E., \& Asonitou, S. (2010). The approaches to learning of European accounting students. EuroMed Journal of Business, 5(3),

345-362. http://dx.doi.org/10.1108/14502191011080854

The objective of this research was to identify a mechanism through which the impact of differing teaching contexts on the approaches to learning of accounting undergraduates in different countries could be measured initially and as changes were made. The results of the research show that the revised SPQ (Biggs et al., 2001) identified differences between Greek, Spanish and UK students in terms of their approaches to learning and between the gender groups in each individual country. The presage model (Biggs, 1987, 1993a and 1993b) indicates that the approaches to learning adopted by students are a function of student factors and teaching context. These underlying factors and there effects on the quality of learning outcomes should be the subject of further research.

There is pressure for the international harmonisation of accounting practice. The accounting profession internationally has been involved in a process of harmonization created by the global financial market. The creation and implementation of standards has been the focus of considerable professional and academic activity. Globalisation was identified by Albrecht and Sack (2000) as being a factor in creating the need for change in accounting and subsequently accounting education. There is pressure for the education of accountants to become standardized and harmonized. The Professional Common Content Statement for professional accountancy qualifications stated: "Working together, our aim is that by 2005 our national qualifications will be common except for those elements of national law, custom and practice, which are still different. Once this common framework is established, we hope the premier accounting bodies across the rest of Europe and, indeed, around the world will wish to join us. It will do much to equip coming generations of accountants for the truly global economy of the future". Whilst the above comments were predominantly aimed at professional qualifications there will inevitably be an impact on the education that future accountants receive during their studies at university. Initiatives such as the European Higher Education Area (Bologna process) also create pressure for the standardisation of educational 
Preprint of the paper: Arquero, J.L., González González, J.M., Hassall, T., Joyce, J., Germanou, E., \& Asonitou, S. (2010). The approaches to learning of European accounting students. EuroMed Journal of Business, 5(3), 345-362. http://dx.doi.org/10.1108/14502191011080854

practice. However, it is clear that comparably little interest has been shown in the harmonization of standards for the education of accountants. Needles (1992) states: "Gaining an understanding of the various practices in the education of accountants throughout the world may provide insight into the differences in applying accounting and auditing standards". More importantly Needles then continues: "But a fundamental issue arising in the efforts to harmonize standards for accounting and auditing relates to the extent to which the differences in the application of these standards may exist due to the differences in the education and qualifications of accountants and auditors". This is further supported by González et al. (2009) who suggest that the mere translation of educational practices that have been successful in their countries of origin without taking into account contextual differences is problematical and could result in undesired consequences. Thus identifying an approach capable of indicating and measuring the underlying reasons why the quality of the learning outcomes achieved may differ under differing educational systems is instrumental to a successful process of change for the future of accounting education. 
Preprint of the paper: Arquero, J.L., González González, J.M., Hassall, T., Joyce, J., Germanou, E., \& Asonitou, S. (2010). The approaches to learning of European accounting students. EuroMed Journal of Business, 5(3), 345-362. http://dx.doi.org/10.1108/14502191011080854

Figure 1. The 3P model of teaching and learning

PRESAGE

PROCESS

PRODUCT

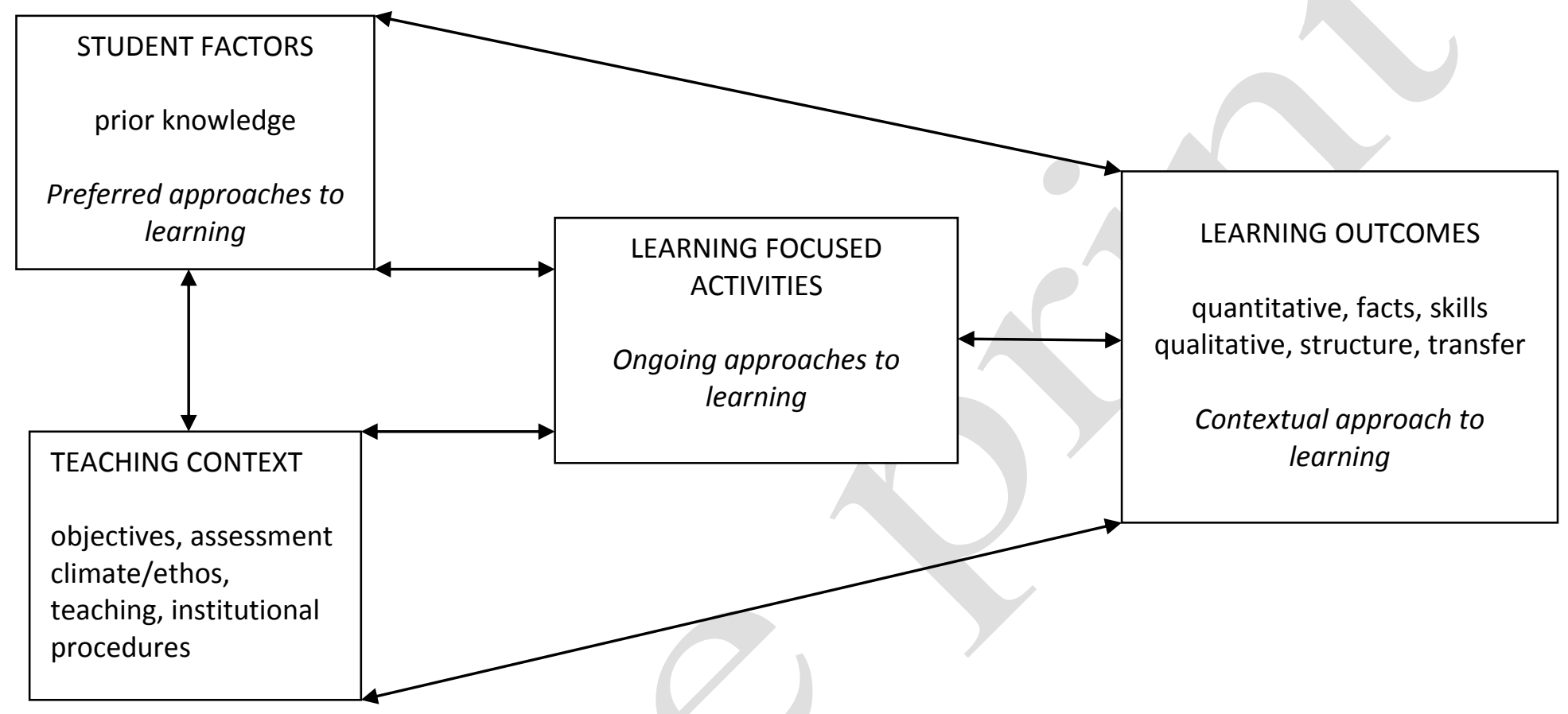

Source: (Biggs, 1987, 1993a and 1993b). 
Preprint of the paper: Arquero, J.L., González González, J.M., Hassall, T., Joyce, J., Germanou, E., \& Asonitou, S. (2010). The approaches to learning of European accounting students. EuroMed Journal of Business, 5(3), 345-362. http://dx.doi.org/10.1108/14502191011080854

\section{REFERENCES}

Accounting Education Change Commission (1990), Objectives of Education for Accountants (Position Statement No. 1), Accounting Education Change Commission, New York.

Albrecht, W.S. and Sack, R.J. (2000), Accounting Education: Charting the Course through a Perilous Future, Accounting Education Series, Vol. 16, American Accounting Association, Sarasota, FL.

Arquero, J.L. and Donoso, J.A. (2007), "Problem Solving Styles, Approaches to Learning and Academic Performance of Spanish Accounting Students: An Exploratory Study of Profiles and Relationships". Paper presented at the 30th European Accounting Association Conference, Lisbon.

Biggs, J.B., Kember, D. and Leung D.Y.P. (2001), “The revised two-factor study process questionnaire: R-SPQ-2F”, British Journal of Educational Psychology, Vol. 71, pp. 133149.

Biggs, J.B. (1987), Student approaches to learning and studying, Australian council for Educational Research, Camberwell, Vic.

Biggs, J.B. (1993a), "What do inventories of students' learning processes really measure? A theoretical review and clarification", British Journal of Educational Psychology, Vol. 63, pp. $1-17$.

Biggs, J.B. (1993b), "From theory to practice: A cognitive systems approach", Higher Education Research and Development, Vol. 12, No. 1, pp. 73-86.

Booth, P., Luckett, P. and Maldenovic, R. (1999), "The quality of learning in accounting education: the impact of approaches to learning on academic performance", Accounting Education: An International Journal, Vol. 8, No. 4, pp. 277-300.

Byrne, M., Flood, B. and Willis, P. (2002), "Approaches to Learning of European Business Students", Journal Of Further And Higher Education, Vol. 26, No. 1, pp. 19-29.

Byrne, M., Flood, B. and Willis, P. (2004a), "Using the Student Learning Framework to Explore the Variation in Academic Performance of European Business Students", Journal Of Further And Higher Education, Vol. 28, No. 1, pp. 67-78.

Byrne, M., Flood, B. and Willis, P. (2004b), "Validation of the Approaches and Study Skills Inventory for Students (ASSIST) using accounting students in the United States and Ireland: a Research note", Accounting Education: An International Journal, Vol. 13, No. 4, pp. 449-459.

Davidson, R. (2002), "Relationship of study approach and exam performance", Journal of Accounting Education, Vol. 20, No. 1, pp. 29-44.

Entwistle, N. and Ramsden, P. (1983), Understanding Student Learning, Croom Helm, London.

Fox, R., McManus, I. and Winder, B. (2001), "The shortened Study Process Questionnaire: An investigation of its structure and longitudinal stability using confirmatory factor analysis", British Journal of Educational Psychology, Vol. 71, pp. 511-530.

Gibbs G. (1992), Improving the quality of student learning, Technical and Educational Services, Bristol.

Gibbs, G. (1995), Assessing Student Centred Courses, Oxford Centre for Staff Development, Oxford.

Gibbs, G. (1999), "Using assessment strategically to change the way students learn”, in: Brown, S. And Glasner, A. (Eds.), Assessment matters in higher education: choosing and using diverse approaches, Open University Press, Buckingham, pp. 41-53. 
Preprint of the paper: Arquero, J.L., González González, J.M., Hassall, T., Joyce, J., Germanou, E., \& Asonitou, S. (2010). The approaches to learning of European accounting students. EuroMed Journal of Business, 5(3), 345-362. http://dx.doi.org/10.1108/14502191011080854

González, J.M., Arquero, J.L. and Hassall, T. (2009), "Bologna and beyond: a comparative study focused on UK and Spanish accounting Education", Higher Education in Europe, Vol. 34, No. 1, pp. 113-125.

Hayes, K. and Richardson, J.E. (1995), "Gender, subject and context as determinants of approaches to studying in higher education", Studies in Higher Education, Vol. 20, No. 2, pp. 215-221.

Kember, D., Wong, A., and Leung, D.Y.P. (1999), "Reconsidering the dimensions of approaches to learning” British Journal of Educational Psychology, Vol. 69, pp. 323-343.

Marton F. and Saljo R. (1976), "On qualitative differences in learning - 1 Outcome and process", British Journal of Educational Psychology, Vol. 46, pp. 4-11.

Marton F. and Saljo R. (1984), "Approaches to learning", in Marton et al. (Eds.) The Experience of Learning, Scottish Academic Press, Edinburgh.

Needles, B.E., Kantor, J. and Shoenthal, E.R. (1992), "Global compliance with international accounting education guidelines", Accounting Education, Vol. 1, No. 3, pp. 211 - 224.

Paul De Lange, P. and Mavondo, F. (2004), "Gender and motivational differences in approaches to learning by a cohort of open learning students", Accounting Education: An International Journal, Vol. 13, No. 4, pp. 431-448.

Ramburuth, P. and Mladenovic, R. (2004), "Exploring the relationship between students' orientations to learning, the structure of students' learning outcomes and subsequent academic performance", Accounting Education: An International Journal, Vol. 13, No. 4, pp. 507-527.

Ramsden, P. (1992), Learning to teach in higher education, Routledge, London.

Ramsden, P. and Entwistle, N. (1981), "Effects of academic departments on students' approaches to studying”, British Journal of Educational Psychology, Vol. 51, pp. 368383.

Richardson, J.T.E. (1993), "Gender differences in responses to the Approaches to Studying Inventory", Studies in Higher Education, Vol.18, No. 1, pp. 3-13.

Richardson, J.T.E. (2000), Researching Student Learning: Approaches to Studying in Campusbased and Distance Education, SRHE and Open University Press.

Scouller, K. (1998), "The influence of assessment method on students' learning approaches: multiple choice question examination versus assignment essay", Higher Education, Vol. 35, pp. 453-472.

Severiens, S.E. and Ten Dam, G.T.M (1998), "A multilevel meta-analysis of gender differences in learning orientations", British Journal of Educational Psychology, Vol. 68, pp. 595608.

Shuell, T.J. (1986), “Cognitive conceptions of learning”, Review of Educational Research, Vol. 56, pp. 411-436.

Smith, S.N. and Miller, R.J. (2005), "Learning approaches: examination type, discipline of study, and gender", Educational Psychology, Vol. 25, No. 1, pp. 43-53.

Sundem G.L. and Williams D.Z. (1992), "Changes in accounting education: preparing for the twenty-first century", Accounting Education: An International Journal, Vol. 1, No. 1, pp. 55-61.

Trigwell, K. and Prosser, M. (1991), "Relating approaches to study and the quality of learning outcomes at the course level", British Journal of Educational Psychology, Vol. 61, pp. 265-275. 
Preprint of the paper: Arquero, J.L., González González, J.M., Hassall, T., Joyce, J., Germanou, E., \& Asonitou, S. (2010). The approaches to learning of European accounting students. EuroMed Journal of Business, 5(3), 345-362. http://dx.doi.org/10.1108/14502191011080854

Vermunt, J.D. (2005), "Relations between student learning patterns and personal and contextual factors and academic performance", Higher Education, Vol. 49, pp. 205-234.

Volet S.E. and Chalmers D. (1992), "Investigation of qualitative differences in university students' learning goals based on an unfolding model of stage development", British Journal of Educational Psychology, Vol. 62, pp. 17-34.

Watkins, D. (1982), "Identifying the study process dimensions of Australian university students", Australian Journal of Education, Vol. 26, pp. 76-85.

Zeegers, P. (2002), “A Revision of the Biggs' Study Process Questionnaire (R-SPQ)”, Higher Education Research \& Development, Vol. 21, No. 1, pp. 73-92.

Zeff, S.A. (1989), "Recent trends in accounting education and research in the U.S.A.: some implications for UK academics", British Accounting Review, Vol. 21, No. 2, pp. 159-176. 